\title{
Cases of Acute Meningitis in Children, Admitted and Treated in Prince Hashim Military Hospital in Zarqa-Jordan
}

\author{
Osama R Atoom, Ayoob A Shakoury*, Zeyad S Bataineh, Ehab N Zraikat and Shadi H Shweiyat \\ Royal Medical services, Jordan
}

*Corresponding author: Ayoob A Shakoury, Royal Medical services, Jordan

\section{ARTICLE INFO}

Received: 慧 February 03, 2019

Published: 蔧 February 27, 2019

Citation: Osama R Atoom, Ayoob A Shakoury*, Zeyad S Bataineh, Ehab N Zraikat, Shadi H Shweiyat. Cases of Acute Meningitis in Children, Admitted and Treated in Prince Hashim Military Hospital in Zarqa-Jordan. Biomed J Sci \& Tech Res 15(2)-2019. BJSTR. MS.ID.002680.

Keywords: Acute Meningitis; Prince Hashim Military Hospital; Zarqa-Jordan

\begin{abstract}
Introduction: Meningitis is a medical emergency caused by a rare infection that affects the delicate membranes called "meninges" that cover the brain and spinal cord. Acute Meningitis can be septic or aseptic. Aseptic meningitis is an inflammation of the meninges with sterile bacterial cultures of Cerebrospinal Fluid (CSF). The most common causes of aseptic meningitis are viral infections that usually get better without treatment. Aseptic meningitis may be also due to "partially-treated" bacterial meningitis, tuberculous or fungal meningitis. However, acute bacterial meningitis is a true medical emergency, and it can be life-threatening and spreads between people in close contact with each other, which requires immediate treatment in a hospital. Viral meningitis is milder and occurs more often than bacterial meningitis. It usually develops in the late summer and early fall; most infections occur in children under the age of 5 years. The aim of this study is to evaluate and outline the seasonality, clinical features, and percentage of aseptic meningitis cases among Jordanian children in Zarqa governorate which may help to decrease the empiric use of antibiotics and the length of hospital stay.
\end{abstract}

Material and Methods: A Prospective observational study was conducted in Prince Hashim military hospital in Zarqa. Participants of the study were patients, admitted and diagnosed with meningitis during the study period (between 1/12/ 2016 to 30/11/2017). Patients' history, complains, laboratorial analysis, vaccinations, and treatment were studied. Cases were divided to groups according to the age.

Descriptive in addition to some inferential statistics such as t-test, ANOVA, and odds ratio calculation were used to analyze the results.

Finding: Total of 206 children were admitted to Prince Hashim Military Hospital with acute meningitis, $53 \%$ were under two years old, with male to female ratio (1.4:1). Majority of the cases happened in summer and autumn 55\%, the least were in spring 20\%. Mean number of WBC in CSF was significantly different in the three age groups; the highest was in 2-5 years group of age, No significant difference in means of CSF protein, sugar and serum sugar among the three age groups. One of these cases had a positive CSF culture (strept. pneumonia). Fever and vomiting were a universal presenting complaint in the three age groups. Convulsions mainly decrease with increasing of age, but headache is an increasing complaint by age. Before the admissions $41 \%$ of patients were given antibiotics (oral or parenteral), and during the hospitalization all patients were treated with third generation cephalosporin.

Conclusion: With respect to CSF analysis, Culture, age and seasonal distribution, most patients in our study were suspected to have viral meningitis, but they were treated as bacterial meningitis because of lack of additional lab. investigations such as viral study to confirm the diagnosis. The use of expensive antibiotics such as 3rd generation cephalosporin in all patients with meningitis including viral cases, in addition to the long stay in hospital (on average of nine days per patient) which constitute a heavy economic burden on RMS budget. This economic burden can be greatly reduced if we have proper diagnostic procedures to diagnose viral meningitis, which decreases days of admission per patient and eliminates the irrational use of antibiotics. 


\section{Introduction}

Bacterial meningitis is a serious life-threatening disease affecting the nervous system that needs immediate medical intervention. And the neurological sequel in such conditions following hospital discharge approaches $20 \%$. So, it is essential for physicians to understand the clinical signs and symptoms of the disease and its management and prevention [1-4]. Worldwide Meningitis can occur independently of age health status in spite of introduction of vaccines and availability of antibiotics.

Acute Meningitis may be septic or aseptic. Aseptic meningitis is an inflammation of the meninges with sterile bacterial cultures of Cerebrospinal Fluid (CSF). The most common cause of aseptic meningitis are viral infections that usually get better without treatment [5-7]. Aseptic meningitis may be also due to "partiallytreated" bacterial meningitis, tuberculosis or fungal meningitis. However, acute bacterial meningitis is a true medical emergency, and requires immediate treatment in a hospital $[8,9]$.

Viral meningitis is milder and occurs more often than bacterial meningitis. It usually develops in the late summer and early fall; most infections occur in children under the age of 5 years [1012]. Most viral meningitis cases (90\%) are due to non-polio enteroviruses, which are viruses that also cause intestinal illness. About half of these cases are caused by the Coxsackie virus and echovirus (two members of the enterovirus family), herpes and mumps virus can also cause viral meningitis [13-15].

\section{Objectives}

The purpose of this study was to establish the seasonality, clinical features, and percentage of aseptic meningitis cases among Jordanian children in Zarqa governorate which may help to decrease the empiric use of antibiotics and the length of hospital stay.

\section{Material and Methods}

A Prospective observational study was conducted in Prince Hashim military hospital in Zarqa. Participants of the study were patients, admitted and diagnosed as meningitis during the study period (between 1/12/ 2016 to 30/11/2017).

\section{Sampling}

Data were collected by a special questionnaire which was filled by direct interview with the parents and data recorded in the patients file. Cases were divided to three groups according to their age (1 month - 2 years, 2 - 5 years and more than 5 years). Patients' history, complains, laboratorial analysis, vaccinations, and treatment were studied. The clinical criteria for diagnosis of meningitis were clinical picture suggestive of meningitis in addition to the presence of pleocytosis (high WBC number in CSF).

\section{Statistical Methods}

Descriptive in addition to some inferential statistics such as t-test, ANOVA, and odds ratio calculation were used to analyze the results.

\section{Results}

Total of 206 children who were admitted to Prince Hashim Military Hospital with acute meningitis, 53\% were under two years old, with male to female ratio (1.4:1). Five were excluded. (Do not fulfill the criteria of the study) Majority of the cases happened in summer and autumn 55\%, the least were in spring $20 \%$ as shown in Table 1 (Figure 1). Mean number of WBC in CSF was significantly different in the three age groups; the highest was in (2-5 years ) group of age, then the age group of ( 5 or more) then the age group of ( $1 \mathrm{~m}-2)$ years respectively as shown in Table 2 (Figure 2).

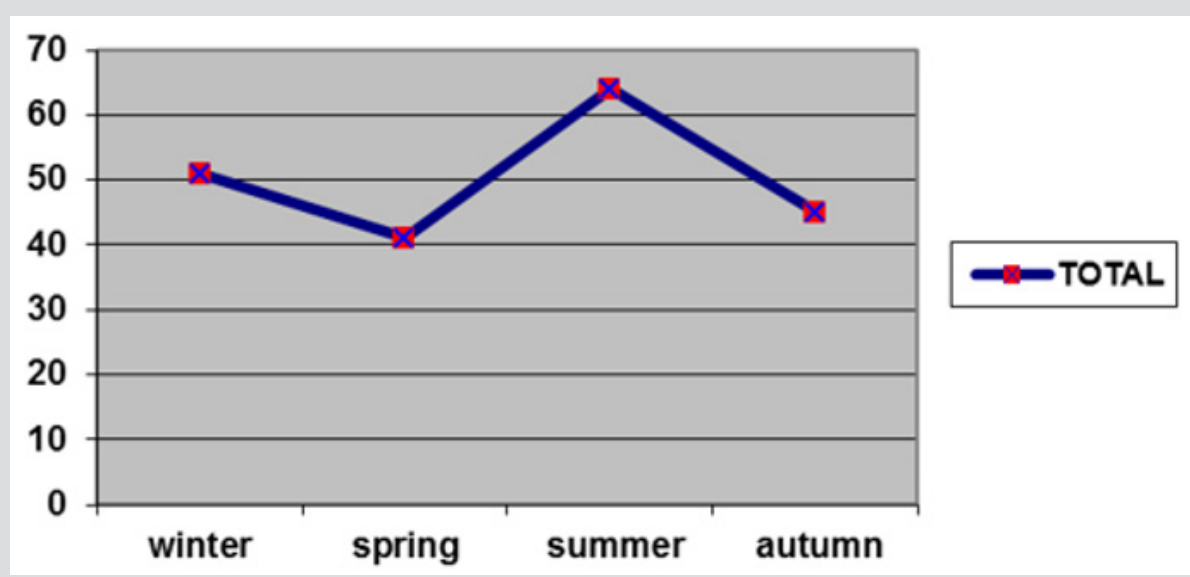

Figure 1: Most cases of meningitis mainly occur during summer and autumn (55\%).

Table 1: Seasonal distribution of meningitis cases.

\begin{tabular}{|c|c|c|c|c|c|c|c|c|c|c|c|c|c|c|}
\hline \multirow[t]{2}{*}{ Age Group } & \multicolumn{3}{|c|}{$\begin{array}{l}\text { Winter } \\
12,1,2\end{array}$} & \multicolumn{3}{|c|}{$\begin{array}{l}\text { Spring } \\
3,4,5\end{array}$} & \multicolumn{3}{|c|}{$\begin{array}{c}\text { Summer } \\
6,7,8\end{array}$} & \multicolumn{3}{|c|}{$\begin{array}{l}\text { Autumn } \\
9,10,11\end{array}$} & \multirow[t]{2}{*}{ Total } & \multirow[t]{2}{*}{ Percent } \\
\hline & M & $\mathbf{F}$ & $\mathbf{T}$ & M & $\mathbf{F}$ & $\mathbf{T}$ & M & $\mathbf{F}$ & $\mathbf{T}$ & M & $\mathbf{F}$ & $\mathbf{T}$ & & \\
\hline $1 / 12$ - 2 YEARS & 15 & 6 & 21 & 14 & 6 & 20 & 21 & 20 & 41 & 14 & 11 & 25 & 107 & $53 \%$ \\
\hline $2-5$ YEARS & 6 & 6 & 12 & 4 & 3 & 7 & 7 & 4 & 11 & 4 & 3 & 7 & 37 & $19 \%$ \\
\hline 5 YEARS OR MORE & 9 & 9 & 18 & 7 & 7 & 14 & 8 & 4 & 12 & 9 & 4 & 13 & 57 & $28 \%$ \\
\hline
\end{tabular}




\begin{tabular}{|c|c|c|c|c|c|c|c|c|c|c|c|c|c|c|}
\hline TOTAL & 30 & 21 & 51 & 25 & 16 & 41 & 36 & 28 & 64 & 27 & 18 & 45 & 201 & $100 \%$ \\
\hline M: F RATIO & \multicolumn{3}{|c|}{$1.4: 1$} & \multicolumn{3}{|c|}{$1.7: 1$} & \multicolumn{3}{|c|}{$1.3: 1$} & \multicolumn{3}{|c|}{$1.5: 1$} & & \\
\hline TOTAL M+F & \multicolumn{3}{|c|}{$51=25 \%$} & \multicolumn{3}{|c|}{$41=20 \%$} & \multicolumn{3}{|c|}{$64=32 \%$} & \multicolumn{3}{|c|}{$45=23 \%$} & $100 \%$ & \\
\hline TOTAL PATIENTS & \multicolumn{14}{|c|}{201} \\
\hline
\end{tabular}

Table 2: Mean CSF results in the three age groups.

\begin{tabular}{|c|c|c|c|c|c|}
\hline Age group & Mean WBC number & $\begin{array}{c}\text { Mean CSF Protein } \\
\mathbf{m g} / \mathbf{d l}\end{array}$ & $\begin{array}{c}\text { Mean CSF Sugar } \\
\mathbf{m g} / \mathbf{d l}\end{array}$ & Mean S.Sugar mg/dl & CSF Sugar/S.Sugar \\
\hline 1MONTH - 2 YEARS & 107 & 32.5 & 53.3 & 89.6 & $60 \%$ \\
\hline 2 - 5 YEARS & 331 & 33.9 & 54.4 & 87 & $63 \%$ \\
\hline 5 YEARS OR MORE & 158 & 34 & 53.4 & 93.6 & $57 \%$ \\
\hline ANOVA TEST & P - VALUE $=0.046$ & P-VALUE $=0.89$ & P-VALUE $=0.94$ & P- VALUE $=0.47$ & \\
\hline
\end{tabular}

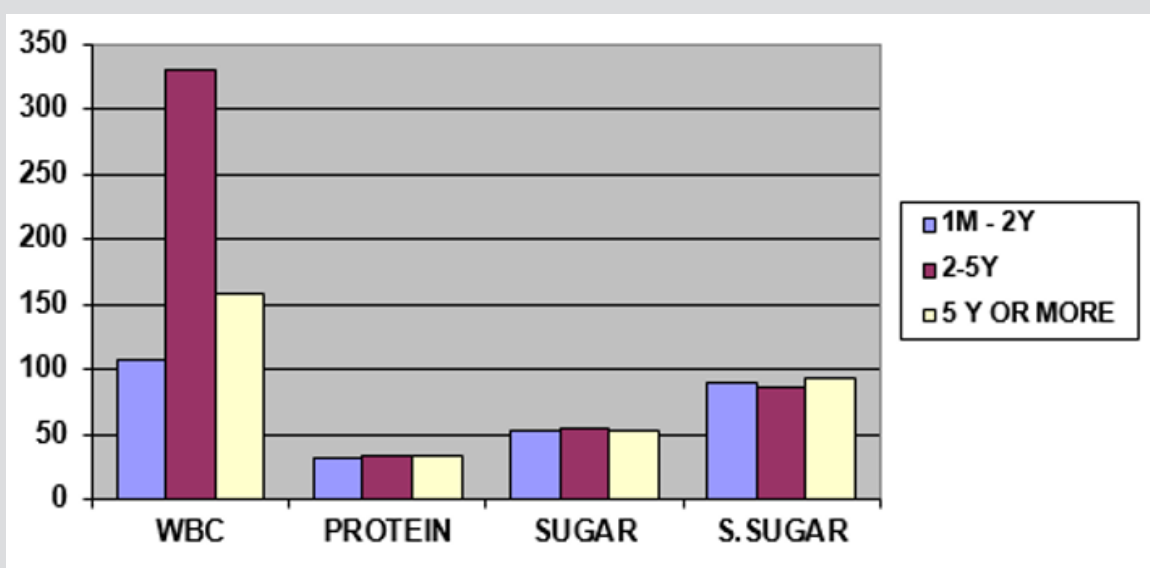

Figure 2: Mean CSF results for the three age groups.

No significant difference in means of CSF protein, sugar and serum sugar among the three age groups.

One of these cases had a positive CSF culture (strept.pneumonia). Fever and vomiting were a universal presenting complaint in the three age groups. Convulsions mainly decrease with increasing of age but headache is an increasing complaint by age, Table 3 (Figure
3). Before the admissions $41 \%$ of patients were given antibiotics (oral or parenteral), and during the hospitalization all patients were treated with third generation cephalosporin, and (98\%) of these patient were vaccinated up to date (Table 4). Cephalosporin were given to all patients, Vancomycin were given to $6 \%$ of patient, but Ampicillin was given to $20 \%$ of patients mainly in early infancy (Figure 4).

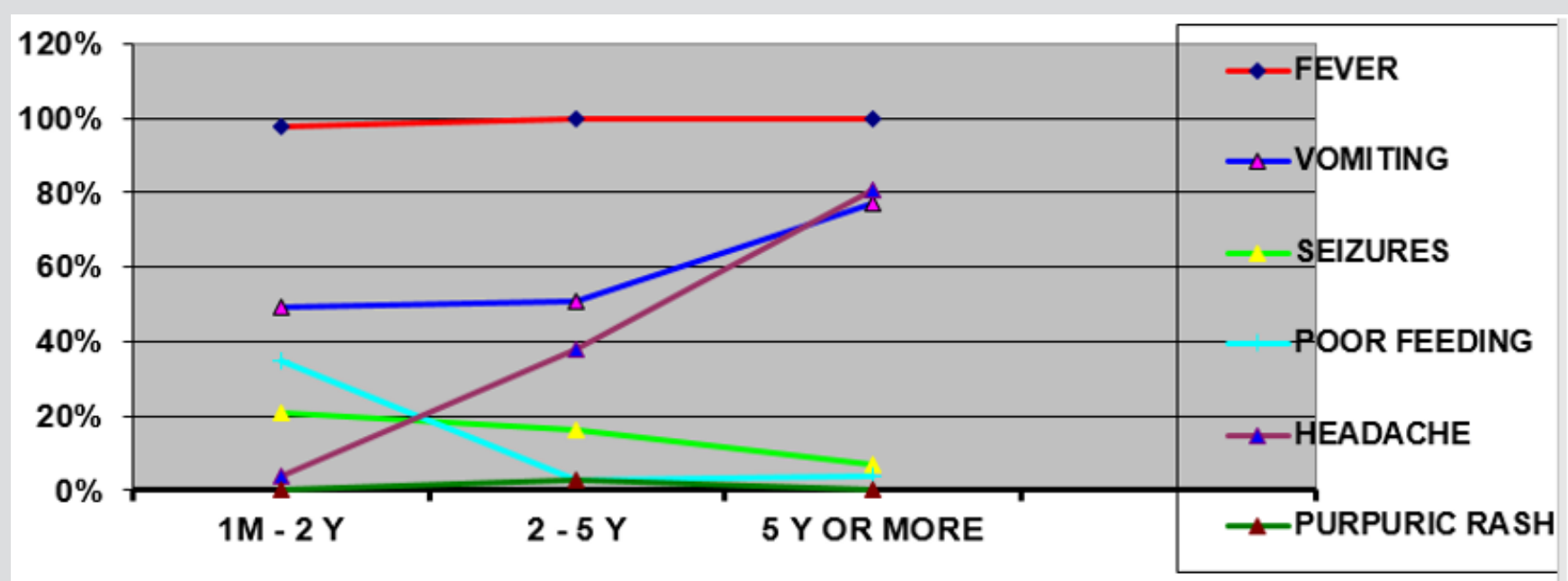

Figure 3: Frequency of presenting complaints in different age groups. 


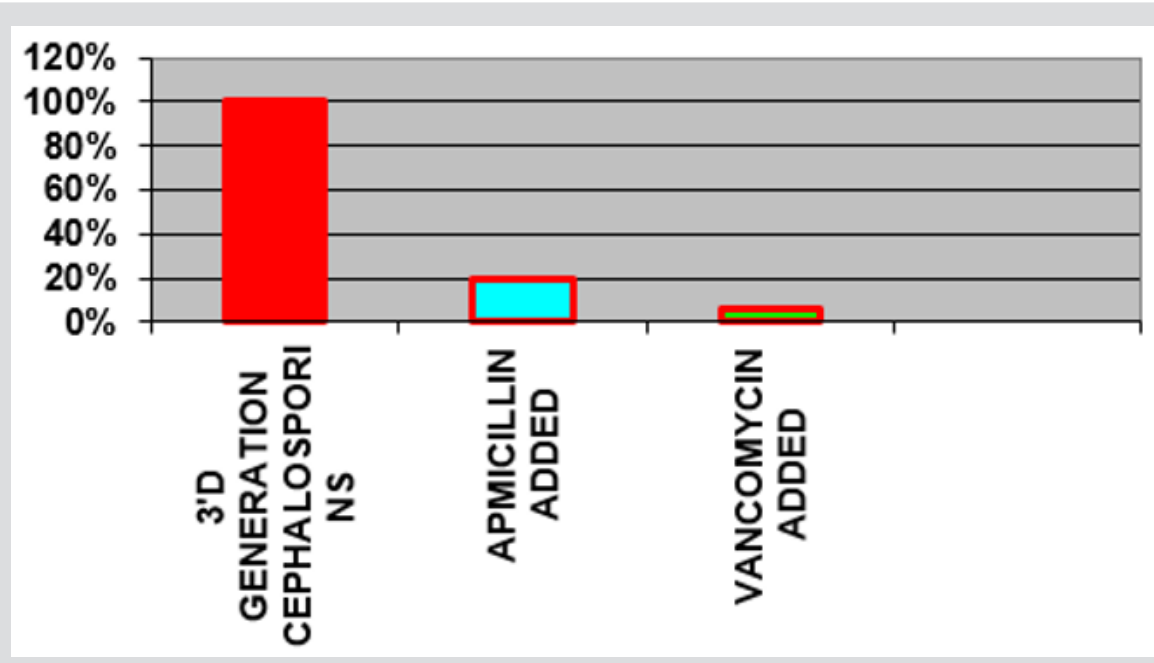

Figure 4: Antibiotics used in all patients.

Table 3: Presenting complaint.

\begin{tabular}{|c|c|c|c|c|c|c|}
\hline Age group & Fever & Vomiting & Seizures & Poor feeding & Headache & Purpuric rash \\
\hline $\begin{array}{c}1 \mathrm{M}-2 \text { 2YEARS } \mathrm{n} \\
=107\end{array}$ & $\begin{array}{l}105 \\
98 \%\end{array}$ & $\begin{array}{c}52 \\
49 \%\end{array}$ & $\begin{array}{c}22 \\
21 \%\end{array}$ & $\begin{array}{c}37 \\
35 \%\end{array}$ & $\begin{array}{c}4 \\
4 \%\end{array}$ & 0 \\
\hline $\begin{array}{c}2-5 \text { YEARS } \\
\mathrm{N}=37\end{array}$ & $\begin{array}{c}37 \\
100 \%\end{array}$ & $\begin{array}{c}19 \\
51 \%\end{array}$ & $\begin{array}{c}6 \\
16 \% \\
\end{array}$ & $\begin{array}{c}1 \\
3 \%\end{array}$ & $\begin{array}{c}14] \\
38 \%\end{array}$ & $\begin{array}{c}1 \\
3 \%\end{array}$ \\
\hline $\begin{array}{l}5 \text { YEARS OR MORE } \\
\quad \mathrm{N}=57\end{array}$ & $\begin{array}{c}57 \\
100 \%\end{array}$ & $\begin{array}{c}44 \\
77 \%\end{array}$ & $\begin{array}{c}4 \\
7 \%\end{array}$ & $\begin{array}{c}2 \\
4 \%\end{array}$ & $\begin{array}{c}46 \\
81 \%\end{array}$ & 0 \\
\hline
\end{tabular}

Table 4: Antibiotics given during the present illness prior to admission \& vaccination.

\begin{tabular}{|c|c|c|c|c|}
\hline \multirow{2}{*}{ Age Group } & Antibiotic & Antibiotic & \multicolumn{2}{|c|}{ Vaccination } \\
\cline { 2 - 5 } & Not given & Given & Up to Date & 4 \\
\hline $\begin{array}{c}1 \text { M }-2 \text { YEARS } \\
\text { N }=107\end{array}$ & 68 & 39 & 37 & 03 \\
\hline $\begin{array}{c}2-5 \text { YEARS } \\
\text { N= 37 }\end{array}$ & 16 & 21 & 57 & 0 \\
\hline $\begin{array}{c}5 \text { YEARS OR MORE } \\
\text { N= } 57\end{array}$ & 34 & 23 & $197(98 \%)$ & $4(2 \%)$ \\
\hline TOTAL & $118(59 \%)$ & $83(41 \%)$ & & 4 \\
\hline
\end{tabular}

\section{Discussion}

In this study from Zarqa governorate 201 cases of pediatric meningitis were identified over a one-year period. Although not population-based, we are confident that our study captured all inpatient cases in Prince Hashim military hospital in Zarqa, which account for the majority of cases of pediatric meningitis in zarqa governorate. Fever was a universal presenting complaint in the three age groups, vomiting was frequent in the three age groups also, convulsions were mainly decreased with increasing of age, and headache was an increasing complaint in regards of age. $41 \%$ of all patients were given antibiotics (oral or parenteral) prior to admission during the present illness. This may explain partially why most of (CSF) cultures were negative. One Patient 5 years old male of the 201 cases has had a positive CSF culture of strept. Pneumonia.

The Practice Guideline Committee in USA does not recommend routine use of latex agglutination for the rapid determination of the bacterial etiology of meningitis, although some would recommend it for patients with a negative CSF Gram stain results [16]. In this study the CSF LATEX wasn't used. CSF gram stain and differential count for the WBCs in CSF were not available in our hospital lab, during the study period (and are still not available).

Most cases were below 2 years of age (53\%) and occurred during summer and autumn (55\%), which goes with the international studies of patients with viral meningitis. All patients $(100 \%)$ in the current study received antibiotics and were treated as bacterial meningitis inside hospital, although most patients were suspected to have viral meningitis by the clinical picture and CSF findings ,but viral study, gram stain and differential count of WBC in CSF are not available in our hospital. In this study it couldn't take the risk to treat patients as viral meningitis, depending only on routine CSF analysis and culture.

As shown in Tables 5-7 the total cost and economic burden of admissions of patients with meningitis in the hospital is more than 124000 JD per year. (According to prices in year 2016), which could be prevented by using developed diagnostic procedures. 
Table 5: Costs of daily hospital services loaded with admin/finance costs (pediatric department).

\begin{tabular}{|c|c|c|c|c|}
\hline Cost Center & Total Costs & $\begin{array}{c}\text { Admin/Finance } \\
\text { (Loaded) Costs }\end{array}$ & $\begin{array}{c}\text { Total Costs } \\
\text { (TC) + (Loaded }\end{array}$ & $\begin{array}{c}\text { Loaded TC per Adjusted } \\
\text { Patient Day }\end{array}$ \\
\hline Pediatrics & JD 314,722 & JD 95,120 & JD 409,842 & JD 64 \\
\hline
\end{tabular}

Table 6: Total cost of days of admissions.

\begin{tabular}{|c|c|c|c|c|}
\hline Age Group & Mean Days of Admission & Total Days of Admission & Cost of Bed Per Day in J.D & $\begin{array}{c}\text { Total Cost of Admission } \\
\text { Days in J.D }\end{array}$ \\
\hline $\begin{array}{c}1 \text { MONTH }-2 \text { YEARS } \\
\mathrm{n}=107\end{array}$ & 11 & 1177 & $65 J \mathrm{~J}$ & 76505 \\
\hline $\begin{array}{c}2-5 \text { YEARS } \\
\mathrm{n}=37\end{array}$ & 9 & 333 & $65 \mathrm{JD}$ & 21645 \\
\hline 5 YEARS OR MORE $\mathrm{n}=57$ & 7 & 399 & $65 \mathrm{JD}$ & 25935 \\
\hline TOTAL & & 1909 & & 124085 \\
\hline
\end{tabular}

Table 7: Days of admissions and amount of antibiotics used.

\begin{tabular}{|c|c|c|c|c|}
\hline Age Group & Mean Days of Admission & $\begin{array}{l}\text { Mean } \\
\text { B.W Kg }\end{array}$ & $\begin{array}{c}\text { Mean Amount of } \\
\text { Cephalosporins given in } \\
\text { Grams/ Patient during } \\
\text { Admission (120mg/kg/ } \\
\text { day) }\end{array}$ & Total Amount in Grams \\
\hline 1 MONTH -2 YEARS $n=107$ & 11 & 8 & 10.5 grams/ patient & 1123 \\
\hline $2-5$ YEARS $n=37$ & 9 & 14 & 15 grams/patient & 555 \\
\hline 5 YEARS OR MORE $n=57$ & 7 & 25 & 21 grams /patient & 1197 \\
\hline TOTAL & \multicolumn{4}{|c|}{2875} \\
\hline
\end{tabular}

\section{Conclusion}

In respect to CSF analysis, culture, age and seasonal distribution, most patients in our study were suspected to have viral meningitis, but they all were treated as bacterial meningitis because of lack of additional lab. investigations such as CSF latex, viral study, WBCs, differential count and gram stain in CSF to confirm viral infection. The use of expensive antibiotics such as 3rd generation cephalosporin in all patients with meningitis including viral cases, in addition to the long stay in hospital (On average 9 days per patient) constitutes heavy economic burden. This economic burden can be greatly reduced if we have proper diagnostic procedures to diagnose viral meningitis, which decreases the days of admission per patient and eliminates the irrational use of antibiotics.

\section{References}

1. Dorsett M, Liang SY (2016) Diagnosis and treatment of central nervous system infections in the emergency department. Emerg Med Clin North Am 34(4): 917-942.

2. Okike IO, Ribeiro S, Ramsay M, Heath PT, Sharland M, et al. (2014) Trends in bacterial, mycobacterial and fungal meningitis in England and Wales 2004-11: An observational study. Lancet Infect Dis 14(4): 301-307.

3. Campbell H, Borrow R, Salisbury D, Miller E (2009) Meningococcal C conjugate vaccine: The experience in England and Wales. Vaccine 27 (suppl 2): B20-B29.

4. Edmond K, Clark A, Korczak VS, Sanderson C, Griffiths UK, et al. (2010) Global and regional risk of disabling sequelae from bacterial meningitis: A systematic review and meta-analysis. Lancet Infect Dis 10: 317-328.

5. Tacon CL, Flower 0 (2012) Diagnosis and management of bacterial meningitis in the paediatric population: A review. Emerg Med Int 2012: 320309.
6. Ladhani SN, Flood JS, Ramsay ME, Campbell H, Gray SJ, et al. (2012) Invasive meningococcal disease in England and Wales: Implications for the introduction of new vaccines. Vaccine 30(24): 3710-3716.

7. Halperin SA, Bettinger JA, Greenwood B, Harrison LH, Jelfs J, et al. (2012) The changing and dynamic epidemiology of meningococcal disease. Vaccine 30(suppl 2): B26-B36.

8. Mace SE (2008) Acute bacterial meningitis. Emerg Med Clin N Am 26(2): 281-317.

9. Huang WC, Lee CH, Liu JW (2010) Clinical characteristics and risk factors for mortality in patients with meningitis caused by Staphylococcus aureus and vancomycin minimal inhibitory concentrations against these isolates. J Microbiol Immunol Infect 43: 470-477.

10. Teresa Chu (2014) Viral meningitis: An overview. US Pharm 2014(39): HS13-HS15.

11. Thigpen MC, Whitney CG, Messonnier NE, Zell ER, Lynfield R, et al. (2011) Bacterial meningitis in the United States, 1998-2007. N Engl J Med 364(21): 2016-2025.

12. Michael B, Menezes BF, Cunniffe J, Miller A, Kneen R, et al. (2010) Effect of delayed lumbar punctures on the diagnosis of acute bacterial meningitis in adults. Emerg Med J 27: 433-438.

13. Abdolnabi Shabani, Manoochehr Makvandi, Alireza Samarbafzadeh, Ali Teimoori, Mojtaba Rasti, et al. (2018) Echovirus 30 and coxsackievirus A9 infection among young neonates with sepsis in Iran. Iran J Microbiol 10(4): 258-265.

14. Findlow J (2013) Meningococcal group B vaccines. Hum Vaccin Immunother 9: 1387-1388.

15. van de Beek D, de Gans J, Spanjaard L, Weisfelt M, Reitsma JB, et al. (2004) Clinical features and prognostic factors in adults with bacterial meningitis. N Engl J Med 351: 1849-1859.

16. Tunkel AR, Hartman BJ, Kaplan SL, Kaufman BA, Roos KL, et al. (2004) Whitley, practice guidelines for the management of bacterial meningitis. Clinical Infectious Diseases 39: 1267-1284. 
ISSN: 2574-1241

DOI: 10.26717/BJSTR.2019.15.002680

Ayoob A Shakoury. Biomed J Sci \& Tech Res

(C) (P) This work is licensed under Creative

Submission Link: https://biomedres.us/submit-manuscript.php

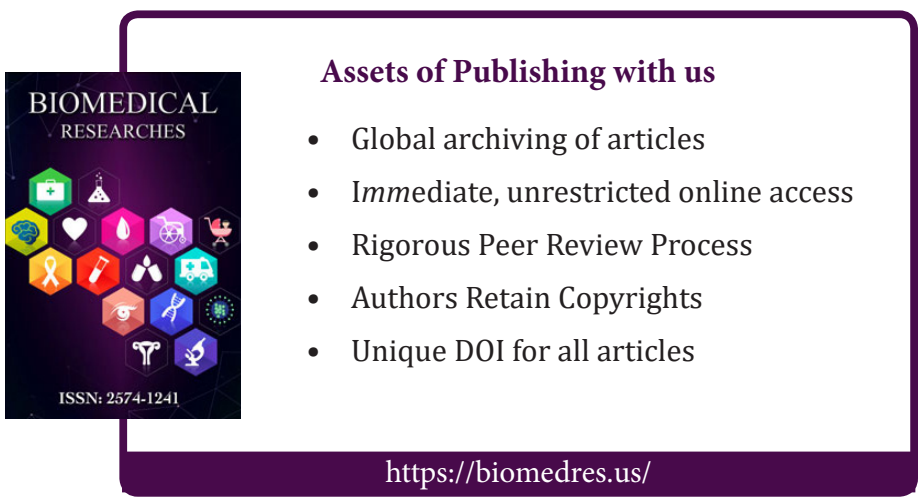

